\title{
Role of sensory neurons on pancreatic beta cell function and on development of insulin resistance
}

\author{
Barna Peitl* , Róbert Döbrönte, László Drimba, Réka Sári, József Németh and \\ Zoltán Szilvássy
}

\author{
Address: Department of Pharmacology and Pharmacotherapy, University of Debrecen, 4032 Debrecen, Hungary \\ Email: Barna Peitl* - barna.peitl@king.pharmacol.dote.hu \\ * Corresponding author
}

\author{
from I5th Scientific Symposium of the Austrian Pharmacological Society (APHAR) Joint meeting with the Hungarian Society of Experimental and Clinical \\ Pharmacology (MFT) and the Slovenian Pharmacological Society (SDF) \\ Graz, Austria. 19-21 November 2009 \\ Published: 12 November 2009 \\ BMC Pharmacology 2009, 9(Suppl 2):A54 doi:10.1186/147I-2210-9-S2-A54
}

This abstract is available from: http://www.biomedcentral.com/I47I-2210/9/S2/A54

(C) 2009 Peitl et al; licensee BioMed Central Ltd.

\section{Background}

To investigate the role of capsaicin-sensitive sensory afferent nerves on the pancreatic beta cell function and on the development of insulin resistance in genetically obese, insulin-resistant Otsuka Long-Evans Tokushima Fatty (OLETF) rats.

\section{Methods}

At the age of 6 weeks, OLETF rats were divided into two groups. The control group was treated with the vehicle for capsaicin, and the capsaicin group was treated with a single subcutaneous dose of $50 \mathrm{mg} / \mathrm{kg}$ capsaicin. The next 19 weeks, the metabolic variables (body weight gain, ingested food and water, stool and urine production) were measured by means of metabolic cages. At the end of the treatment period, the glucose-stimulated insulin response was determined by an oral glucose tolerance test (OGTT), whole body insulin sensitivity was determined by means of hyperinsulinaemic euglycaemic glucose clamping, and the hepatic glucose production (HGP) as well as insulin-stimulated peripheral glucose uptake (PGU) were determined by means of [ $\left.{ }^{3} \mathrm{H}\right]$ glucose infusion. Fasting plasma insulin levels were determined by RIA and fasting blood glucose values by the glucose oxidase method. Pancreatic beta cell function was characterized by the HOMA-B index based on fasting insulin and glucose levels.

\section{Results}

The body weight of the capsaicin-treated group was significantly lower than that of the control group. There were no changes in the other metabolic parameters. During the OGTT, the control group had a reduced glucose-stimulated response compared to the capsaicin-treated group and the area under the curve values were $1844 \pm 124$, and $1287 \pm 87$, respectively $(\mathrm{p}<0.5)$. The whole body insulin sensitivity improved (from $9.4 \pm 1.8$ to $15.6 \pm 2.1 \mathrm{mg} / \mathrm{kg}$ / min) significantly according to the improvement in HGP (from $7.5 \pm 1.5$ to $12.9 \pm 3.1 \mathrm{mg} / \mathrm{kg} / \mathrm{min}$ ) and PGU (from $6.7 \pm 1.2$ to $2.8 \pm 1.1 \mathrm{mg} / \mathrm{kg} / \mathrm{min}$ ). There was no difference in pancreatic beta cell function between the two treatment groups.

\section{Conclusion}

Capsaicin-sensitive sensory afferents play role in the development of obesity and insulin resistance in OLETF rat. To explore the interaction between the $\mathrm{CCK}_{1}$ and TRPV1 receptor in the vagal afferents, further experiments are needed.

\section{Acknowledgements}

The work was supported by the Hungarian Scientific Research Fund (No. $74162)$. 